J. Perinat. Med. 4 (1976) 118

\section{Evaluation of the fetal state by automatic analysis of the heart rate}

\author{
2. Deceleration areas and umbilical artery blood $\mathrm{pH}$
}

\author{
M. Tournaire ${ }^{1}$, G. Sturbois ${ }^{2}$, A. Ripoche ${ }^{3}$, R. Le Houezec ${ }^{4}$, G. Breart ${ }^{5}$, J. Chavinie ${ }^{6}$, \\ C. Sureau ${ }^{7}$
}

One of the difficulties of fetal monitoring is the interpretation of the Fetal Heart Rate (FHR) patterns. Clinical classifications are subjective : Certain patterns are difficult to classify and may be interpreted differently by various readers. We attempted to use FHR deceleration areas as an objective method for evaluating the fetal state. In a previous paper [5], we studied the correlation between the fetal heart rate deceleration areas associated with uterine contractions and the clinical state of new-borns evaluated by 1 minute APGAR score. FHR deceleration areas were found to provide a reasonably good prognostic parameter of the APGAR score, and therefore a good diagnostic factor of the fetal state. In 107 patients, we compared the correlation between the three types of fetal heart rate deceleration areas and umbilical artery blood pH (UApH).

\section{Patients and procedures}

\subsection{Patients:}

This group of 107 patients included 86 cases of the APGAR score study [5] with UApH measure. The average time of monitoring was 110 minutes (from 15 minutes to 6 hours). This group was composed of a large proportion of high risk patients.

Most of the women were given a psychoprophylactic preparation. The use of analgesic drugs was reduced.

\section{Curriculum vitae}

M. TOURNAIRE (M.D.) was born in ClermontFerrand (France) in 1941. He went to medical school in Bordeaux (1959 to 1966) where he received his degree. He was Interne des Hopitaux de Paris from 1968 to 1972, Research Fellow in Perinatal Biology in Dr. HoN's group in 1972 (University of Southern California, Los Angeles).

Since the end of 1972 he has been Chef de Clinique at the Clinique Universitaire Baudelocque, Paris (Chairman: Prof. F. LEPAGE) and has worked in the research unit (Head Prof. Claude SUREAU).

Out of the 107 patients, there 78 spontaneous vertex deliveries, 2 breech deliveries, 14 were delivered by forceps ( 6 with symptoms of acute fetal distress) and 13 by coesarean-section (9 with symptoms of acute fetal distress). For spontaneous vertex and breech deliveries no anesthesia was

1 Chef de Clinique-Assistant-Université René DESCARTES Paris V.

2 Résident étranger du Collège de Médecine des Hôpitaux de Paris.

3 Ingénieur C.N.R.S.-Laboratoire d' Electroencéphalographie et de Neurophysiologie Appliquée (Dr. A: REMOND) Hôpital de la Salpêtrière.

4 Technicien Electronicien-Université René DESCARTES Paris V.

5 Chercheur-Section Maternité Pédiatrie-INSERM (Dir. C. RUMEAU-ROUQUETTE).

6 Professeur Agrégé-Université René DESCARTES Paris V. 7 Professeur-Université René DESCARTES Paris V. 
administered. Low forceps were carried out under pudendal block. For caesarean sections and midforceps, we gave general anesthesia.

\subsection{Procedures}

\subsubsection{FHR deceleration areas}

The method described in the previous publication [5] will only be summarized. We used fetal electrocardiogram ( $R$ wave) obtained by an electrode attached to the presenting part of the fetus, and intrauterine pressure measured with an intrauterine catheter introduced transcervically.

The two signals were transmitted toward:

- a Monitor V Cardiotocograph (Roche Bioelectronics),

- a tape recorder allowing further additional studies,

- the FHR deceleration area computer.

Data (FHR, intrauterine pressure) and results of computation (deceleration areas) were displayed on a strip chart. The results were also shown by digital display.

FHR was expressed in periods, viz., intervals between two fetal heart beats. The two dimensions of FHR deceleration areas (intervals on the ordinate, and time on the abscissa) were expressed in seconds, therefore, the area unit was the "square second" (s2).

We measured three different types of deceleration areas (Fig. 1) according to their time relationship with the uterine contractions (UC): "total" deceleration area (At); "residual deceleration area" (Ar), computed between UC only; "simultaneous" deceleration area during UC only, obtained from the difference between the total and the residual areas. For At and Ar, we obtained the summed area of the whole monitored period directly.

In order to compare the deceleration areas of patients monitored during unequal periods of time, the summed area for the complete tracing of each patient was averaged over a one hour period. Therefore, the result was expressed in square seconds per hour $\left(s^{2} / h\right)$.

\subsubsection{Umbilical artery blood $\mathrm{pH}$}

Within the three minute period following delivery, a sample of artery blood was taken by puncture from a segment of umbilical cord between two forceps.

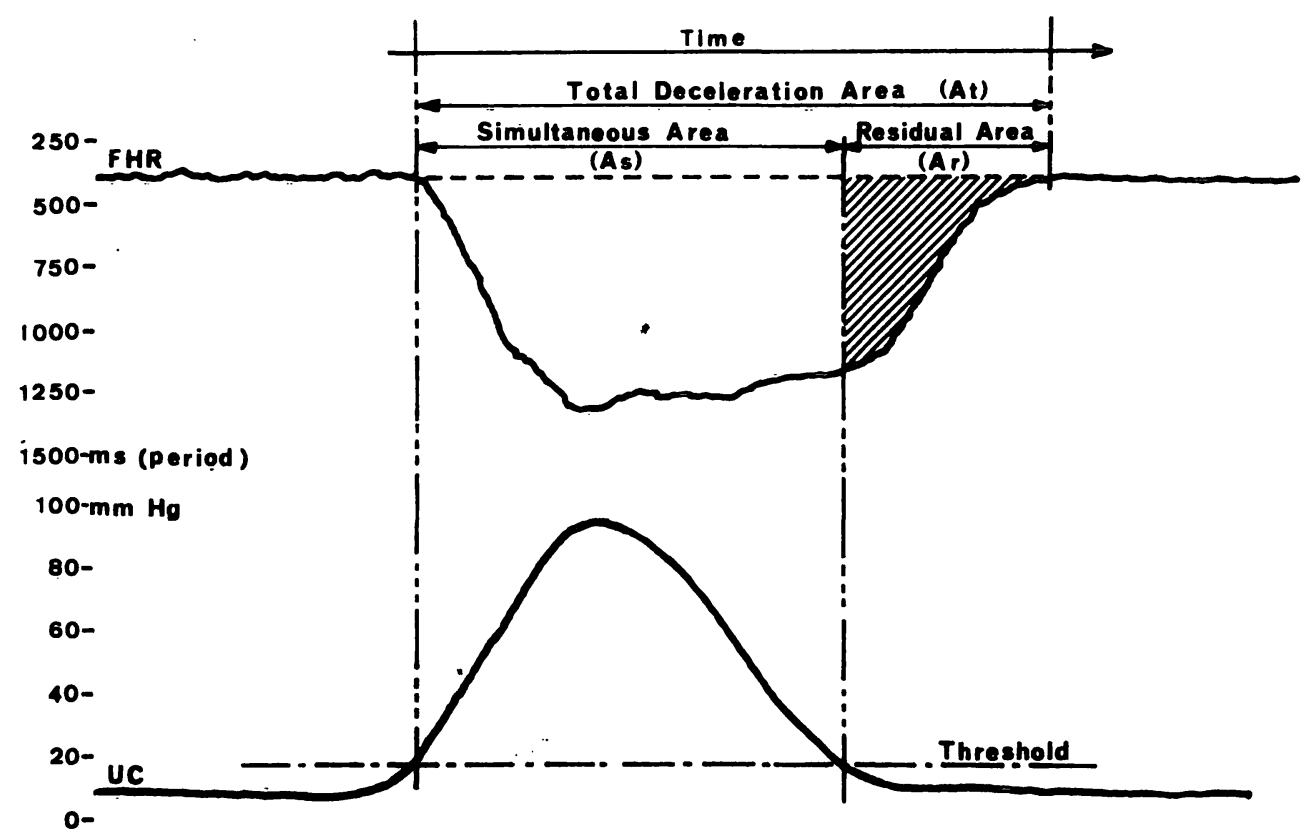

Fig. 1. The three different types of areas measured by the computer.

J. Perinat. Med. 4 (1976) 
Two successive measurements of the $\mathrm{pH}$ were made with a Radiometer microelectrode. We used the average of these two measurements.

2 Results

\subsection{Deceleration areas}

Tab. I. Average deceleration areas per hour.

\begin{tabular}{lc}
\hline AREA & s2/h \\
Simultaneous & 34 \\
Residual & 25 \\
Total & 59 \\
\hline
\end{tabular}

Tab. I shows the average deceleration areas per hour for the 107 patients and for each of the three types of deceleration areas.

\subsection{Umbilical artery $\mathrm{pH}$}

For these 107 newborns, the average umbilical artery blood $\mathrm{pH}$ was 7.23 (standard deviation: 0.085).

In 73 cases $(68 \%)$ it was 7.20 or greater and in 34 cases (32\%) lower than 7.20.

2.3 Correlation between deceleration areas and umbilical artery blood $\mathrm{pH}$

The mean values of the areas were computed for two groups of new-borns (Fig. 1), one with high $\mathrm{UApH}$ ( 7.20 or greater), and one with UApH lower than 7.20 for each type of deceleration area (Fig. 2); there were significantly greater deceleration areas in the lower UApH group (student $t$ test).

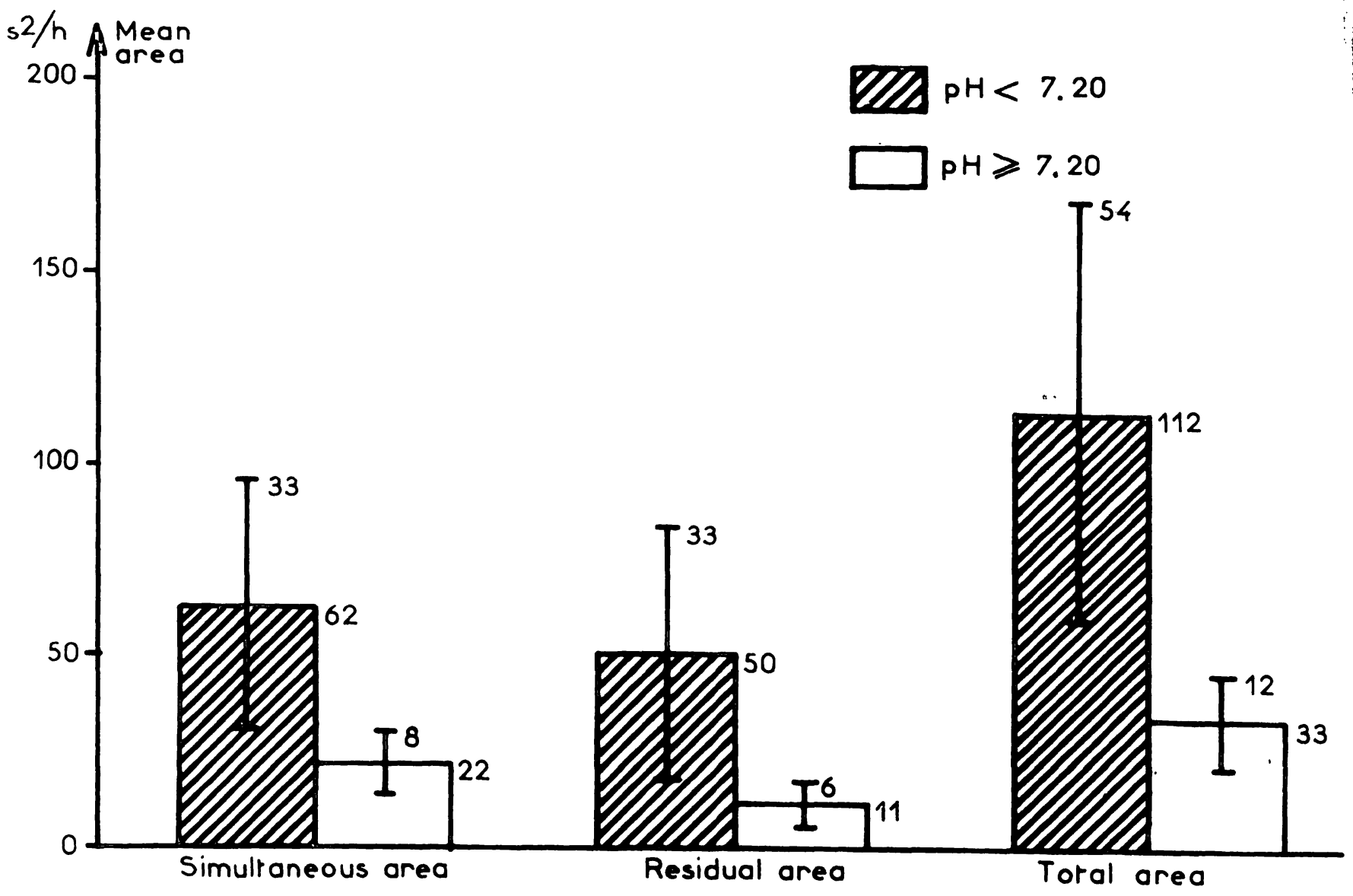

Fig. 2. Mean values of the three types of areas for $\mathrm{pH}<7.20$ and $\mathrm{pH} \geqslant 7.20$ 
2.4 Figures 3 a, b, c, are scattergrams of the 3 different kinds of deceleration areas versus UApH.

Tab. II: Correlation coefficients of deceleration areas and umbilical artery $\mathrm{pH}$.

\begin{tabular}{ll}
\hline AREA & $\begin{array}{l}\text { Correlation } \\
\text { Coefficient }\end{array}$ \\
Simultaneous & -0.44 \\
Redidual & -0.45 \\
Total & -0.51 \\
\hline
\end{tabular}

2.5 Table II shows the correlation between FHR deceleration areas and UApH.

2.6 In the previous paper dealing with the APGAR score [5], we determined for each type of area a limit value of deceleration area, which is an alarm threshold, to predict low (less than 7) or high (7 or more) APGAR scores. We found respectively 70 $\mathrm{s}^{2} / \mathrm{h}, 35 \mathrm{~s}^{2} / \mathrm{h}$ and $105 \mathrm{~s}^{2} / \mathrm{h}$, for simultaneous, residual and total deceleration areas.
These limits were also tested for the UApH (Fig. 4).

There is a highly significant difference for each limit $(P<0.01)$. For example, when At was lower than $105 \mathrm{~s}^{2} / \mathrm{h}, 72$ out of 92 newborns (78\%) had a good $\mathrm{pH}$ and 20 a low one. When At was 105 or greater, 14 out of 15 new-borns had a low pH (96\%). It can be pointed out that in the cases with an area lower than the limit and a low $\mathrm{pH}$, a high proportion had a good APGAR score. For instance, in the 20 cases with $A$ lower than $105 \mathrm{~s}^{2} / \mathrm{h}$ and low $\mathrm{pH}, 11$ had high APGAR scores. Similar results were obtained for As and Ar.

2.7 Figures 6, 7 and 7 are histograms of UApH values for two groups: Area below the limit and an area equal to or greater than the alarm threshold for the three types or areas.

\section{Comments}

The measurement of the FHR deceleration area described by SuREAu since $1968[7,8,9,10,11]$

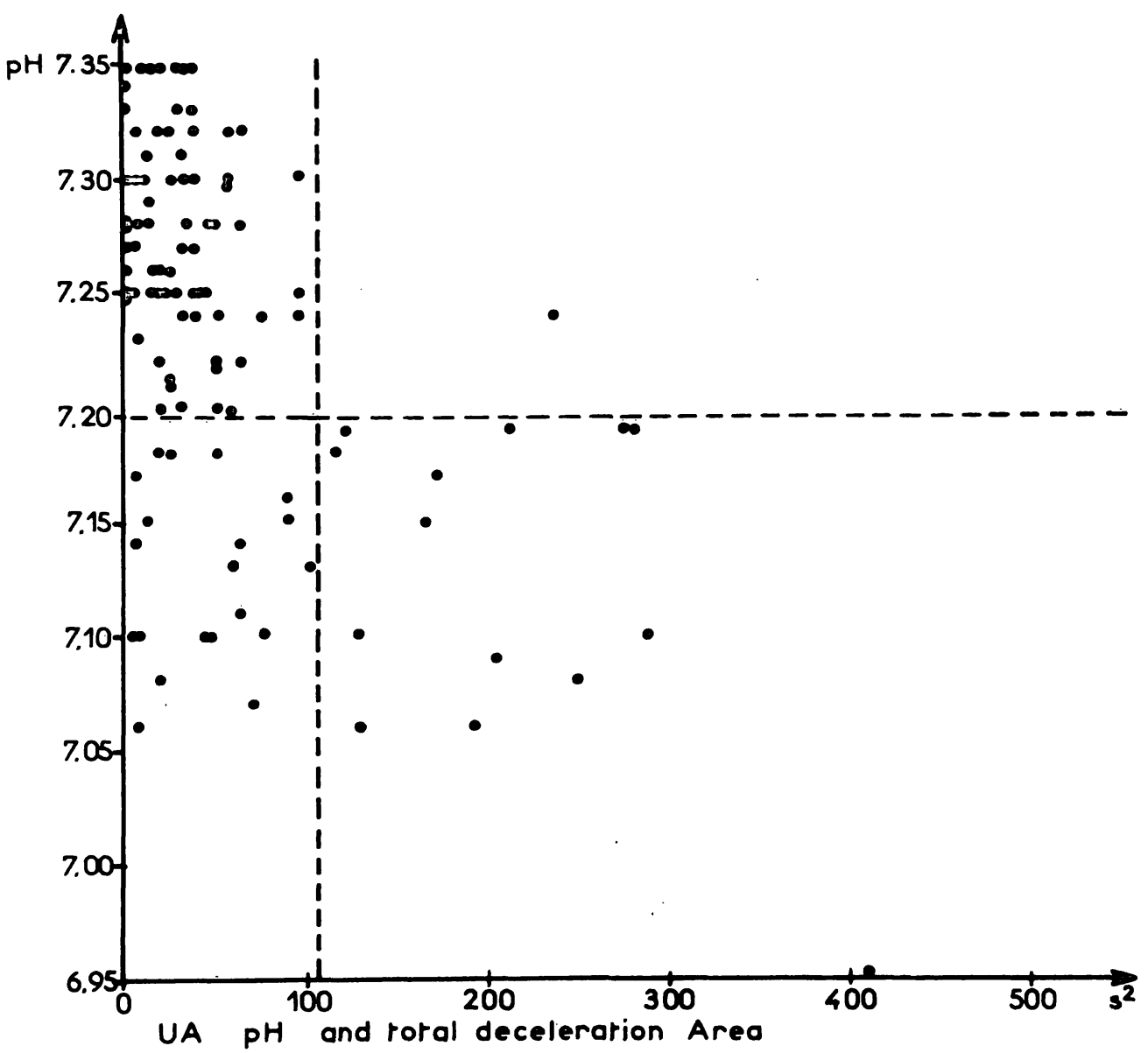

Fig. 3a. UApH and total deceleration area. 


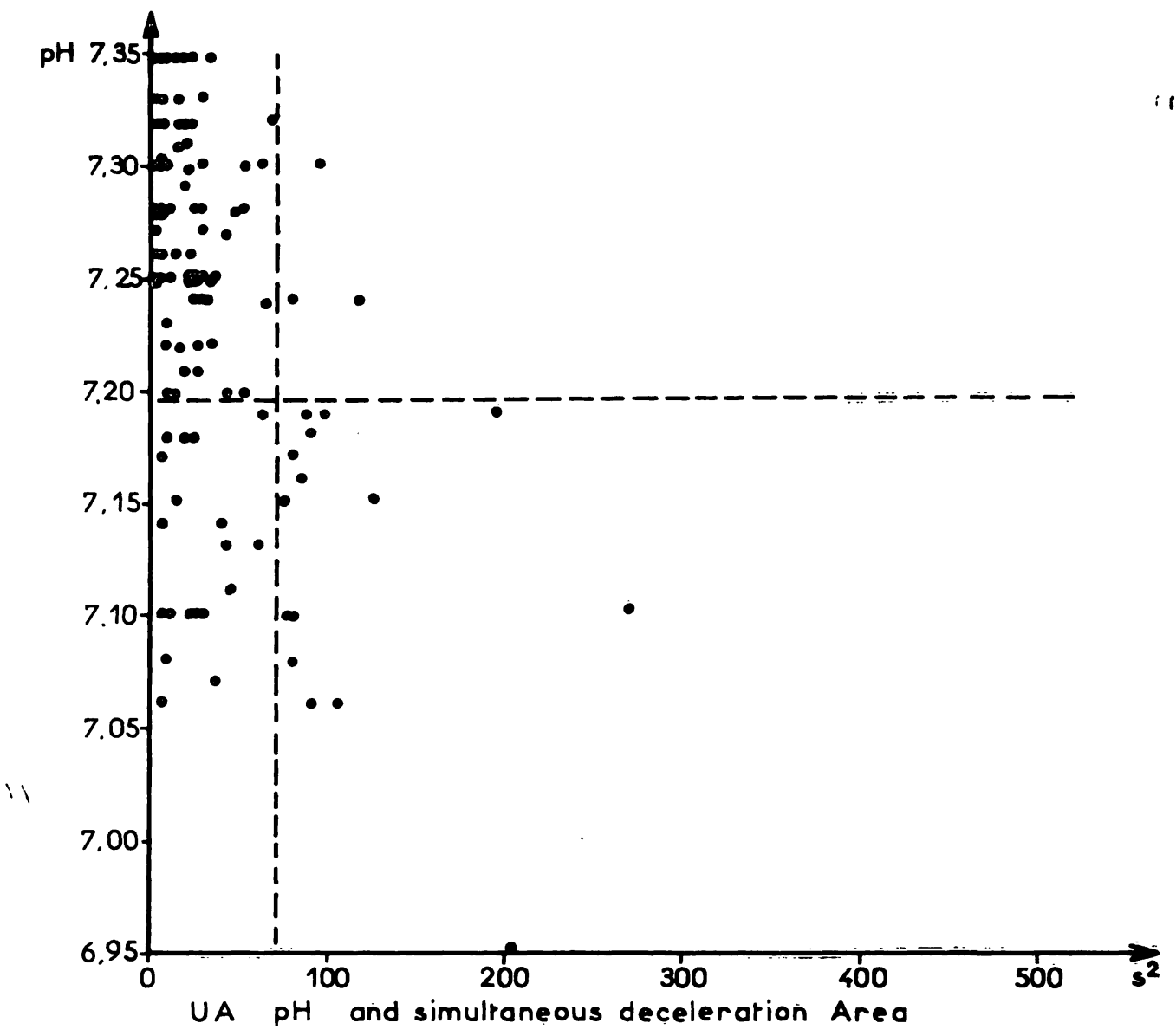

Fig. 3b. UApH and simultaneous deceleration area.

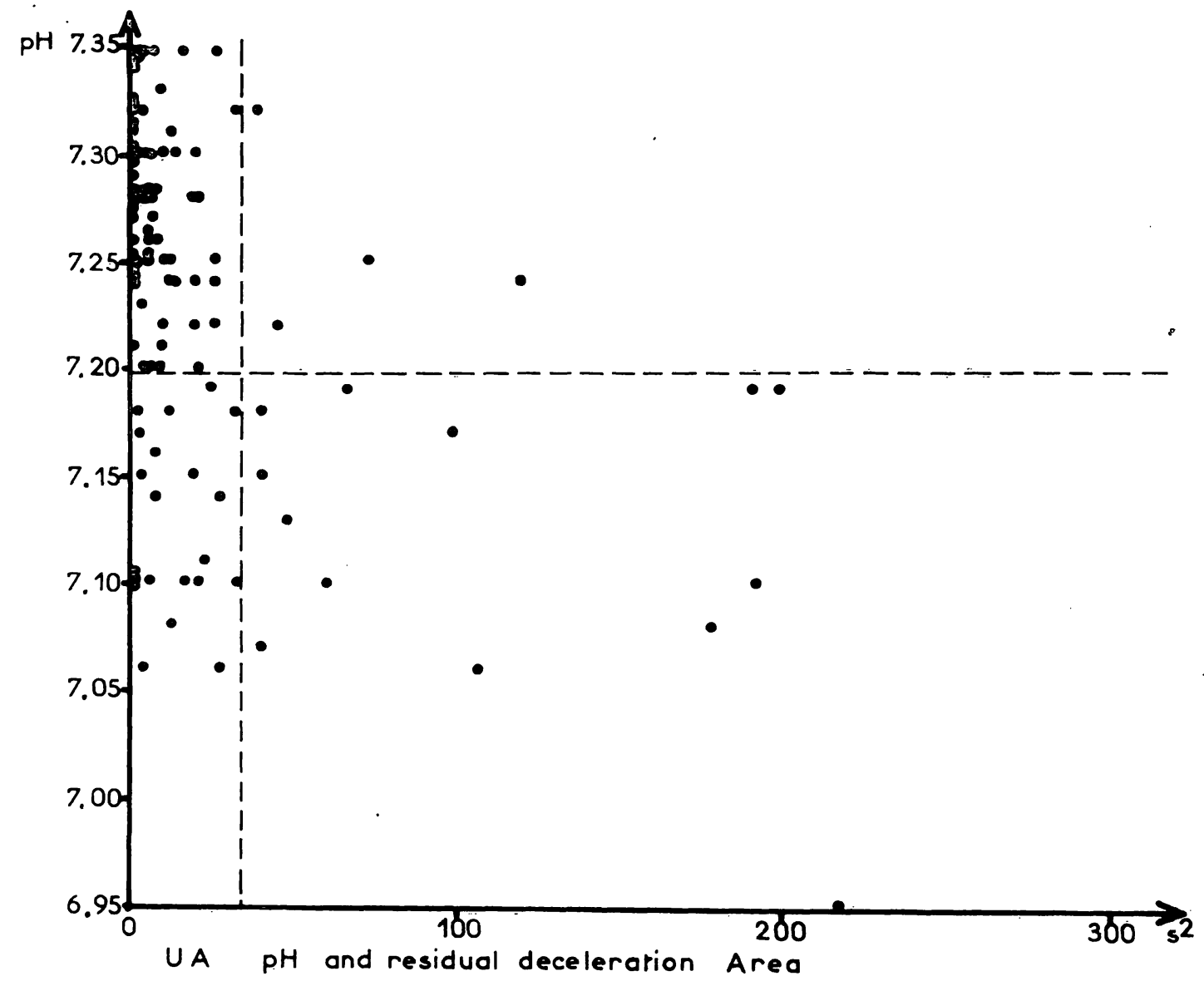

Fig. 3c. UApH and residual deceleration area. 


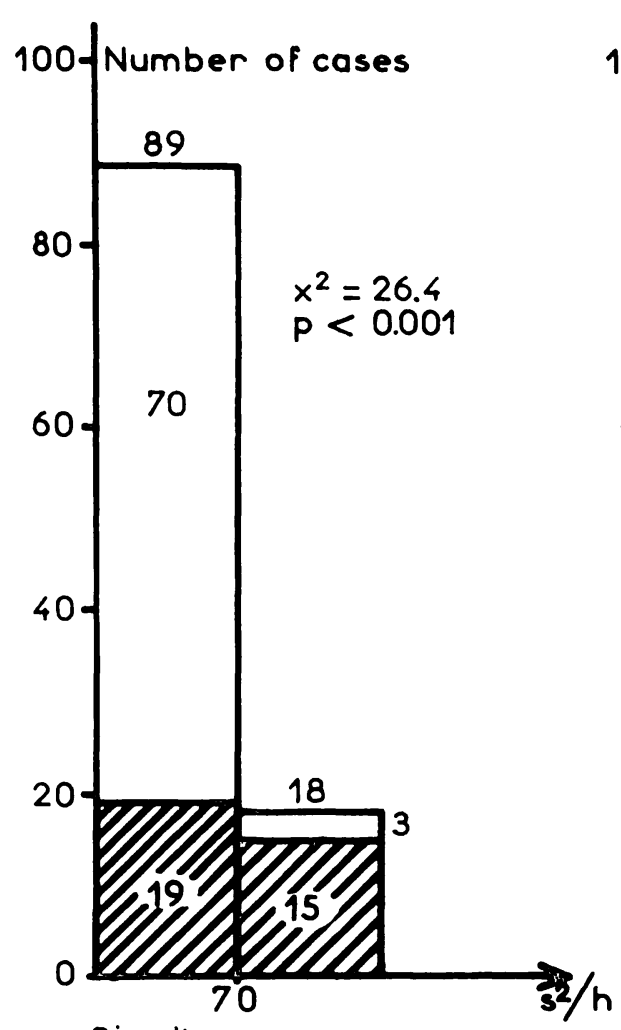

Simultaneous area

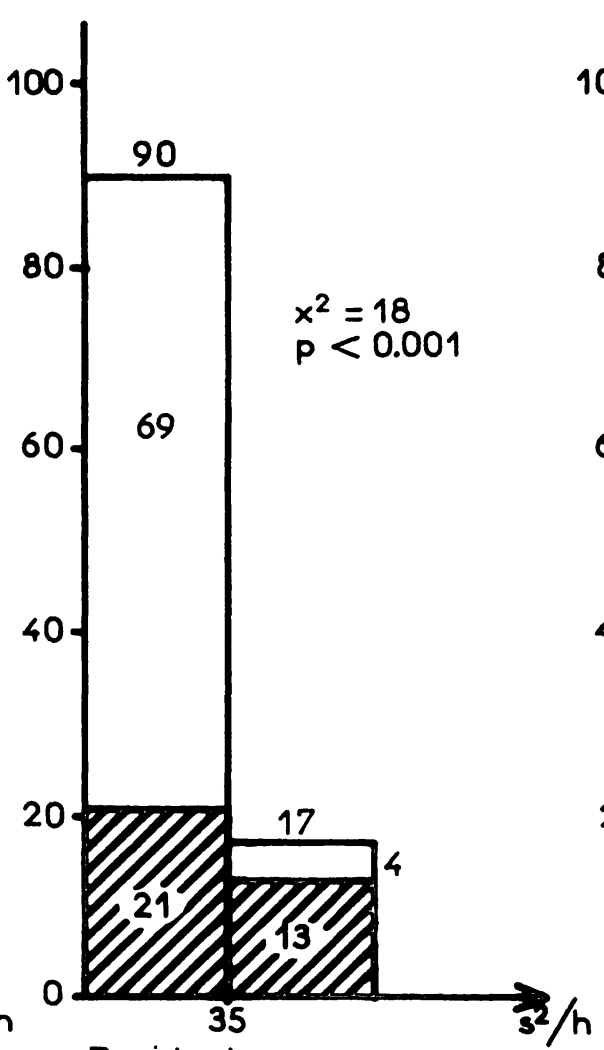

Residual area

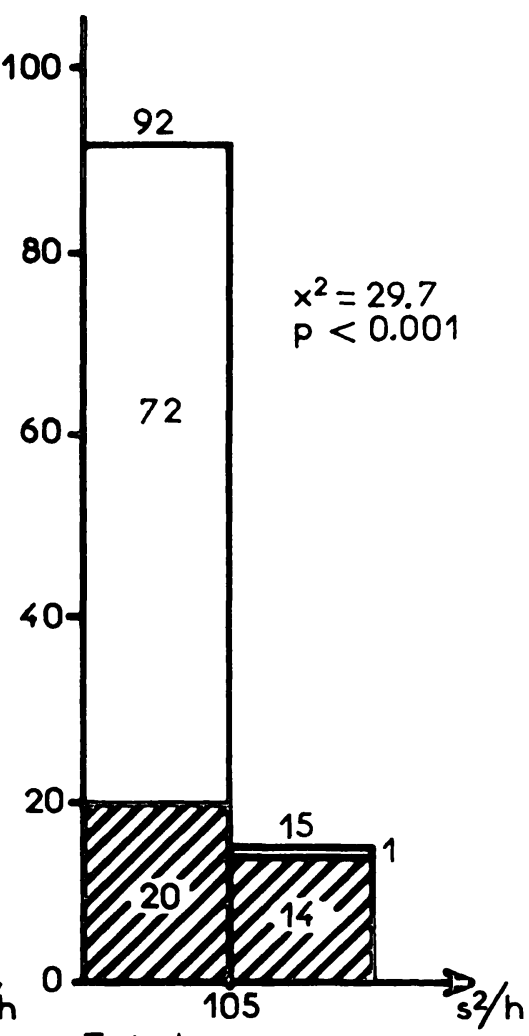

Toral area

WII. $\mathrm{pH}<7.20 \square \mathrm{pH}>7.20$

Fig. 4. Number of new-borns with normal or low UApH under and above the alarm threshold of each area.

is now evaluated according to its ability to predict the biological state of the new-born.

3.1 The first important result, from a clinical viewpoint, is the reasonably good correlation between FHR deceleration areas and UApH (Tab. II). Such a correlation was found by SHELLEY and TIPTON [6] for the whole deceleration area and by TOURNAIRE et. al. [10] for areas divided in a slightly different way. The correlation coefficients of deceleration areas UApH and the APGAG score for this group of 107 patients, are within a close range (Tab. II and III).

Tab. III. Correlation coefficients of deceleration areas and 1 minute APGAR score.

\begin{tabular}{ll}
\hline AREA & $\begin{array}{l}\text { Correlation } \\
\text { Coefficient }\end{array}$ \\
Simultaneous & -0.58 \\
Residual & -0.34 \\
Total & -0.54 \\
\hline
\end{tabular}

Similarly, the correlation coefficient between $\mathrm{UApH}$ and the APGAR score is 0.62. Thus, there is a correlation of similar range for these three factors (APGAR score, UApH and deceleration areas), studied by pairs (Fig. 8).

3.2 "The conclusions obtained from the comparison of the correlation coefficients are debatable because the normality of the distribution is not verified. However, this does not question the association between areas and $\mathrm{pH}$ as it is shown by the $\mathrm{Chi}^{2}$ test".

These results agree with those of SHELLEY and TIPTON [4] suggesting, that in practice, a simple measurement of the whole deceleration area, regardless of the uterine contractions is a sufficient method for evaluating FHR patterns.

In a study done by TournaIRE et al. [10] for 86 patients, the best correlation coefficient was obtained for the equivalent of the residual area $(-0.55)$ but was close to the total area $(-0.53)$. It was -0.41 for the simultaneous area. Com- 

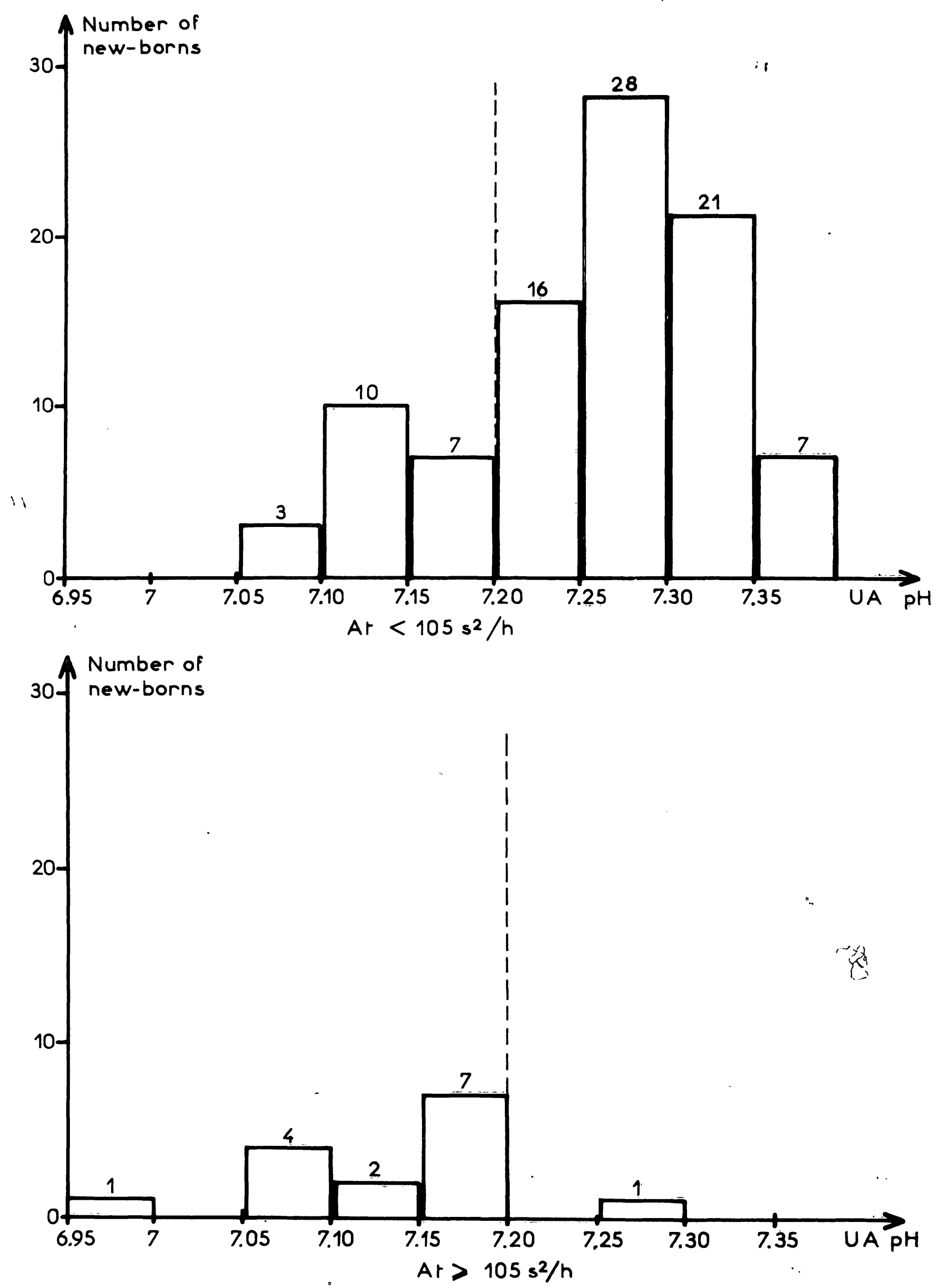

Fig. 5. UApH distribution and total area.

a:At $<105 s^{2} / h$

$\mathrm{b}: A t \geqslant 105 \mathrm{~s}^{2} / \mathrm{h}$ 

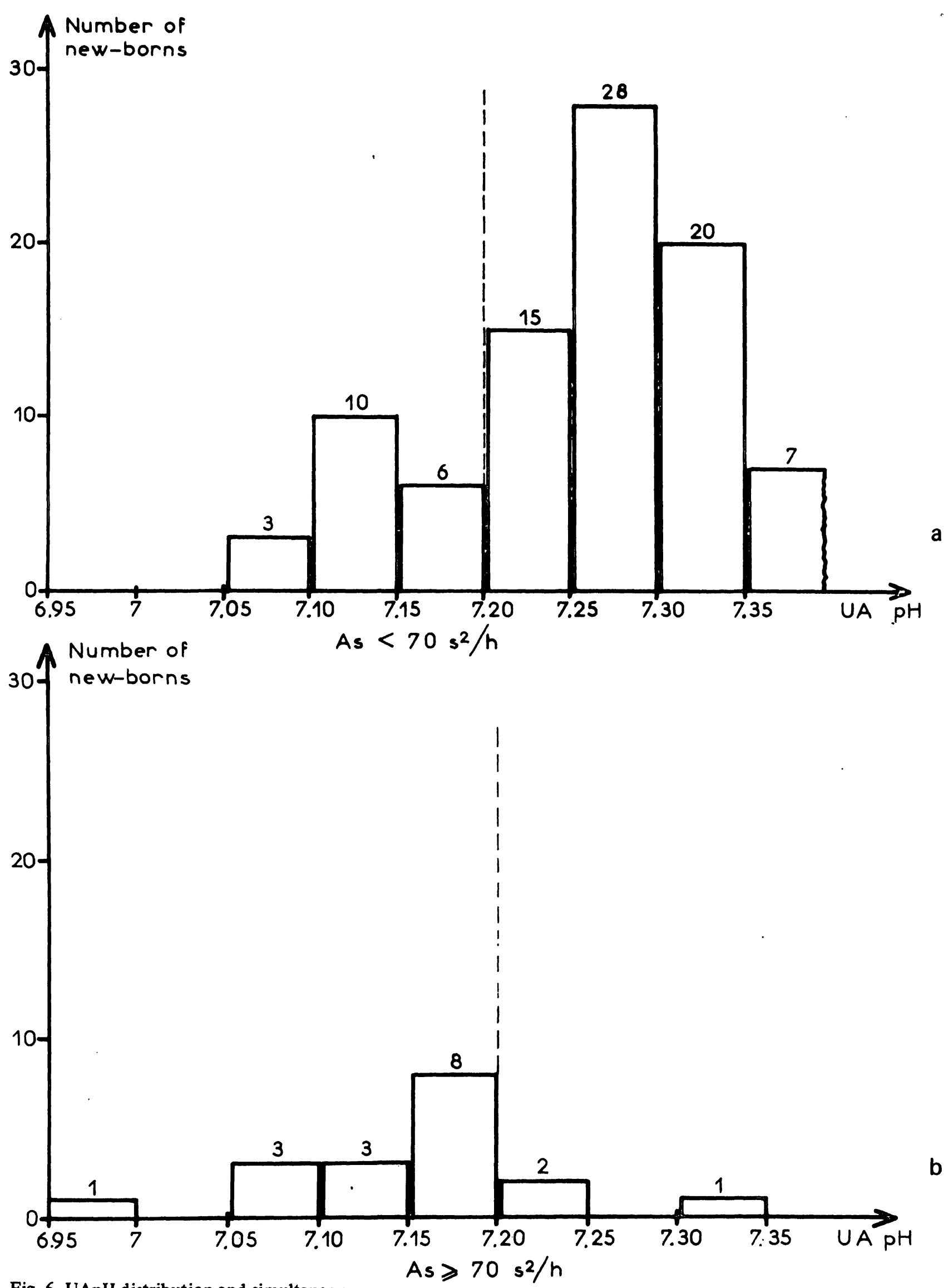

Fig. 6. UApH distribution and simultaneous area. a: As $<70 \mathrm{~s}^{2} / \mathrm{h}$ $\mathrm{b}:$ As $>70 \mathrm{~s}^{2} / \mathrm{h}$

J. Perinat. Med. 4 (1976) 

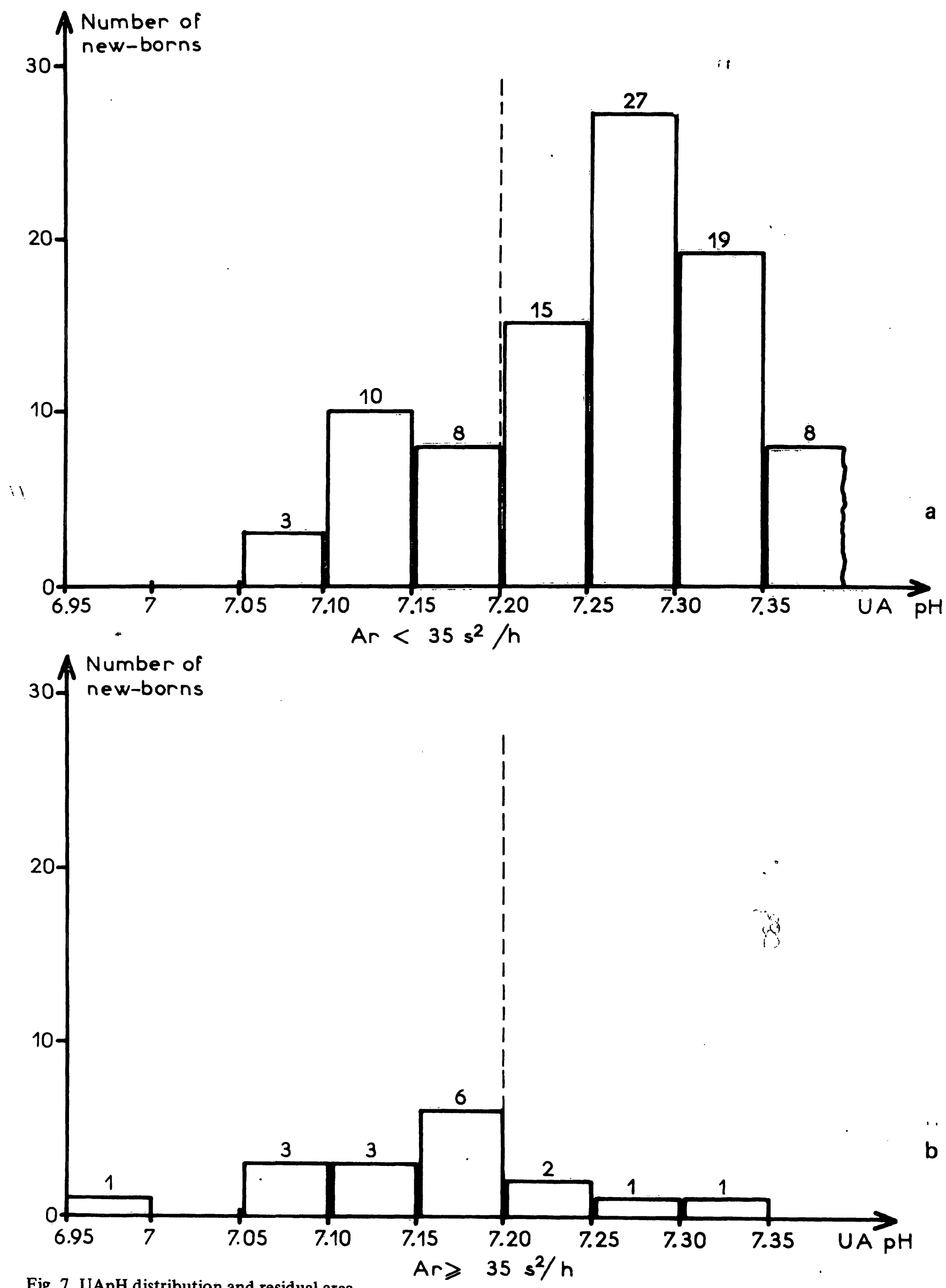

Fig. 7. UApH distribution and residual area. $\mathrm{a}: \mathrm{Ar}<35 \mathrm{~s}^{2} / \mathrm{h} \quad \mathrm{b}: \mathrm{Ar} \geqslant 35 \mathrm{~s}^{2} / \mathrm{h}$ 


\section{Total ceceleration area (At)}

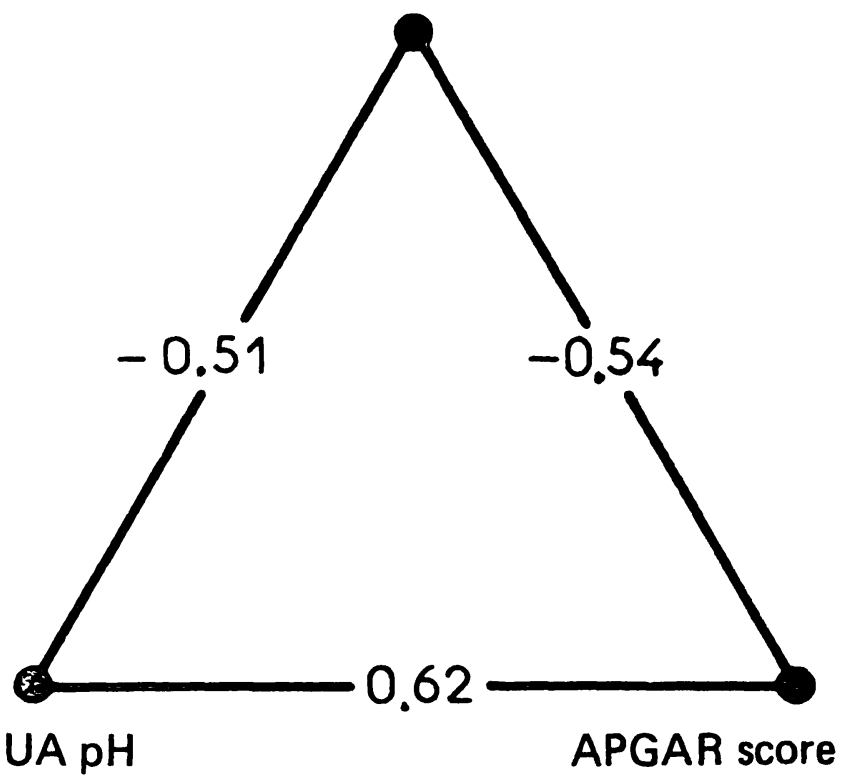

Fig. 8. Correlation coefficients between total deceleration area. APGAR score and umbilical artery blood pH.

pared with the clinical classifications, these results may be surprising because "late" decelerations and prolonged "variable" decelerations are thought to be associated with hypoxia, thus acidosis [1]. One argument may be valid to explain why the residual area did not show the best correlation with UApH. The manner by which we separated the decelerations into different areas makes it difficult to compare it with the clinical classifications: A large part of the prolonged "variable" and also a portion of the "late" deceleration of HoN's classification are measured within our "simultaneous" area.

The physiopathogenic meaning of the lag time between contraction and deceleration could be questioned. MYERS et al. [3] has shown by experimentation with monkeys a direct and higher significant correlation between lag time and $\mathrm{Po}_{2}$ : the shorter the lag time the lower the $\mathrm{Po}_{2}$.

There is a high correlation between the different types of areas. For this reason we studied the coefficients of partial correlation. They show that the relationship between $\mathrm{pH}$ and At is significant even when As or Ar remains constant.

Two other studies have shown the value of the deceleration areas in diagnosing fetal or new-born states: SHELley and TIPTON [4] using retrospective manual measurement and the work done by TOURNAIRE et al. [10] in HoN's group, with a larger specialy programmed computer using recorded data. The special purpose computer used by the BAUDELOCQUE research group can be used on-line, thus in practical obstetrics. The evaluation of deceleration areas appears to have several advantages:

\section{It gives objective measurements.}

2. The units ("square second" in this study, "missed beat" in the works using a frequency scale) are independent of factors such as display speed or scale of the strip-chart.

3. The data is reduced: a few numbers replace the long descriptions of the usual clinical classifications.

However, if this method is a convenient way to evaluate FHR deceleration it will never give more than the information contained in FHR decelerations alone. The absence of deceleration means, with good accuracy, a healthy fetus, but deceleration areas of medium range can be associated with a low or normal Apgar score and $\mathrm{pH}$.

In conclusion, measurement of FHR deceleration areas provides a reasonably good pronostic factor of the clinical and biological state of the new-born.

Its diagnostic value for the biological state of the fetus during labor requires evaluation. Our results were obtained on a population including a large proportion of high risk patients. Further study is needed to complete this investigation, using objective methods to evaluate additional information contained in FHR tracings such as rapid fluctuations of the baseline, the subject of future work.

\section{Summary}

Fetal heart rate (FHR) deceleration areas were studied to obtain by objective measurement of the FHR, their prognostic value of the new-born state.

Patients and Procedures:

In a group 107 patients, we compared three types of FHR deceleration areas. We measured three different types of 
deceleration areas: "total" deceleration area (At); "residual" (Ar) between uterine contractions (UC) and "simultaneous" (As) during UC (Fig. 1). We used foetal electrocardiogram and intra-uterine pressure as primary signals. These two signals were transmitted to the FHR deceleration area special purpose computer. The results were displayed on a strip chart and also shown by digital display. FHR was expressed in periods. The two dimensions of FHR deceleration areas (intervals on the ordinate and time on the abcissa) were expressed in seconds. Therefore, the area unit was the "square second" $s^{2}$.

The summed area for the complete tracing of each patient was averaged over a one hour period. Therefore, the result was expressed in square seconds per hour $\left(\mathrm{s}^{2} / \mathrm{h}\right)$. Umbilical artery blood $\mathrm{pH}$ was measured twice. We used the average of these two measurements.

Results:

1. Tab. I shows the average of each of the three types of deceleration areas.

2. The mean values of the areas was, for each type of area significantly greater in the lower UApH group (UApH lower than 7.20) (Fig. 2).

3. Fig. 3a, b, c are scattergrams of the 3 different kinds of deceleration areas versus UApH.

4. Tab. II shows that the highest correlation coefficient was obtained with total area.

5. The alarm threshold obtained to predict low or high Apgar scores in our previous paper [5] was also tested for the UApH (Fig. 4). There is a highly significant difference between the two groups of patients divided by each threshold. Fig. 5, 6 and 7 are histograms of $\mathrm{UApH}$ evaluated for two groups of areas: above or below the alarm threshold.

\section{Comments:}

The measurement of the FHR deceleration area described by SUREAU since $1968[7,8,9,10,11]$ is evaluated by its ability to predict the biological state of the new-born.
1. There is a reasonably good correlation between FHR deceleration areas and UApH (Tab. II). Such a correlation was found by SHELLEY and TIPTON [6] for the whole deceleration area, and by TOURNAIRE et al. [10] for areas divided in a slightly different way. The correlation coefficients between FHR deceleration areas and Apgar score at 1 minute are within a close range of those of the FHR deceleration area and $\mathrm{UApH}$ (Tab. I and II).

2. According to the time relationship between deceleration areas and uterine contractions the best correlation coefficient was obtained surprisingly for total, followed by residual and then simultaneous areas. These results agree with those of SHELLEY and TIPTON [6] suggesting that in practice a simple measurment of the whole deceleration area, regardless of the uterine contractions is a sufficient method in evaluating FHR patterns.

3. The special purpose computer built by the BAUDELOCQUE research group can be used on-line, thus in clinical practice. It was not the case for the manual method [4] or the method using a large programmed computer [10].

4. The evaluation of deceleration areas appears to have several advantages:

1. It provides objective measurments.

2. The unit used is independant of factors such as display speed or scale of the strip-chart.

3. The data is reduced: A few numbers replace the long descriptions of the usual clinical classifications.

\section{Conclusion:}

In a group of 107 patients including a large proportion of high risk pregnancies, the deceleration area measurment gives an objective evaluation of the FHR tracings with reduced data. It provides a reasonably good prognostic factor of the clinical and biological state of the new-born.

Keywords: Deceleration area, fetal heart rate analysis, $\mathrm{pH}$ of the uterine artery, state of the newborn.

\section{Zusammenfassung}

Bestimmung des fetalen Status praesens durch automatische Analyse der fetalen Herzfrequenz.

II. Decelerationsflächen und aktueller pH im Nabelarterienblut.

In der Arbeit wurden die Decelerationsflächen der fetalen Herzfrequenz untersucht mit dem Ziel, einen objektiven Herzfrequenzparameter von prognostischer Bedeutung für den Zustand des Neugeborenen zu gewinnen.

\section{Patientengut und Methodik:}

Bei einer Gruppe von 107 Patientinnen verglichen wir 3 Typen von Herzfrequenz-Decelerationsflächen: Es wurden 3 verschiedene Typen von Decelerationsflächen bestimmt.

1. Die totale Decelerationsfläche $\left(A_{t}\right)$;

2. die residuale Decelerationsfläche, die jeweils nach den Wehen bestimmt wird $\left(A_{r}\right)$;

3. die simultane Decelerationsfläche $\left(A_{s}\right)$, die während der Wehe anfällt (Fig. 1).
Als Primärsignal verwendeten wir das fetale Elektrokardiogramm und den intrauterinen Druck. Aus diesen beiden Signalen wurde mit Hilfe eines Spezialkomputers die Decelerationisflächen ermittelt. Die Resultate wurden auf einem Lochstreifen fixiert und auch digital ausgegeben. Die fetale Herzfrequenz wurde im Maßstab der Periode ausgedrückt. Die beiden Dimensionen der Decelerationsflächen (Zeitintervall auf der Ordinate und Zeitablauf auf der Abszisse) wurden in Sekunden ausgedrückt. Demzufolge betrug die Dimension der Flächeneinheit SekundenQuadrat $\left(\mathrm{S}^{2}\right)$. Die Decelerationsflächen einer kompletten Aufzeichnung einer Patientin wurden über jeweils 1 Stunde hinweg aufsummiert und dann gemittelt. Folglich werden die Zahlenresultate in Sekunden-Quadrat pro Stunde dimensioniert $\left(S^{2} / h\right)$. Der aktuelle $\mathrm{pH}$ im Nabelarterienblut war jeweils zweimal gemessen worden; verwendet wurde der Mittelwert beider Messungen. 


\section{Resultate:}

1. Tab. I gibt die Mittelwerte der 3 Typen von Decelerationsflächen.

2. Für jeden Decelerationsflächentyp war der Mittelwert jeweils größer in der Gruppe von Patienten mit tieferen pH-Werten (pH in der Nabelarterie < 7,20). (Fig. 2).

3. Figs. 3a, b und $\mathrm{c}$ gibt ein Korrelationsdiagramm der 3 Typen von Decelerationsflächen und des aktuellen $\mathrm{pH}$ in der Nabelarterie.

4. Tab. II zeigt, daß die höchsten Korrelationskoeffizienten beim Rechnen mit der Gesamtfläche erzielt wurden.

5. Die für die Voraussage eines tiefen oder hohen APGARWertes von uns in einer kürzlich erschienenen Arbeit (5) ermittelten "Alarmgrenzwerte" wurden auch für das aktuelle $\mathrm{pH}$ in der Nabelarterie überprüft (Fig. 4). Es besteht eine hochsignifikante Differenz zwischen den beiden durch die Alarmwerte aufgeteilten Patienten-Gruppen. Fig. 5, 6 und 7 zeigen Histogramme und aktuelle pH-Werte in der Nabelarterie; berechnet wurden die beiden Flächengruppen: oberhalb bzw. unterhalb der Alarmgrenzen.

\section{Kommentar:}

Die Ausmessung der Herzfrequenz-Decelerationsflächen wie sie von SUREAU schon $1968[7,8,9,10,11]$ beschrieben wurde, hat sich bewährt und dies auf Grund ihrer Eignung, den biologischen Status praesens des Neugeborenen vorherzusagen.

1. Es existiert eine recht gute Korrelation zwischen der Decelerationsfläche und dem aktuellen $\mathrm{pH}$ in der Nabelarterie (Tab. II). Eine solche Korrelation wurde auch von SHELLEY und TIPTON [6] für die gesamte Decelerationsfläche und von TOURNAIRE und Mitarbeitern [10] für Flächenareale gefunden, die in leicht veränderter Weise aufgeteilt waren. Die Korrelationskoeffizienten zwischen den Decelerationsflächen und der APGAR-Zahl nach 1 Minute gleichen numerisch nahezu jenen zwischen der Decelerationsfläche und dem aktuellen $\mathrm{pH}$ in der Nabelarterie (Tab. I-II).

2. Im Hinblick auf die Verteilung der Flächenareale über der Wehe fand sich die beste Korrelation erstaunlicherweise für die Gesamtfläche gefolgt von der Residualfläche und von dem simultanen Flächenareal. Diese Resultate stimmen mit jenen von SHELLEY und TIPTON [6] überein und lassen vermuten, daß in der Praxis das einfache Ausmessen der gesamten Decelerationsfläche unabhängig von der uterinen Aktivität eine ausreichende Methode ist, um fetale Herzfrequenzkurven zu analysieren.

3. Der von der Forschergruppe an der Klinik BAUDELOQUE konstruierte Spezialkomputer kann on-line, also in der täglichen klinischen Praxis verwendet werden. Dies gilt nicht für die manuellen Auswertungsmethoden [4] oder die Methoden, die einen großen, programmierbaren Komputer voraussetzen [10].

4. Die Bestimmung der Decelerationsflächen scheint mehrere Vorteile zu haben:

1. Sie beinhaltet eine objektive Maßeinheit;

2. die verwendete Einheit ist unabhängig von Faktoren wie Registriergeschwindigkeit oder Maßstab der Herzfrequenz;

3. die Datenmenge wird reduziert, d.h., wenige Zahlen ersetzen die lange Beschreibung der üblichen klinischen Klassifikationskriterien.

\section{Schlußfolgerung:}

Bei einem Kollektiv von 107 Patientinnen, das einen hohen Prozentsatz an Risikoschwangerschaften enthielt, ergab das Ausmessen der Decelerationsflächen einen objektiven Parameter zur Bewertung fetaler Herzfrequenzkurven. Die anfallende Datenmenge wird dabei reduziert. Dieses Flächenmaß ist ein guter und klinisch brauchbarer Parameter für die Vorhersage des klinischen und biologischen Status des Neugeborenen.

Schlüsselworte: Decelerationsflächen, fetale Herzschlagfrequenz, Nabelarterien-pH, Zustand des Neugeborenen, Zustandsdiagnostik.

\section{Resumé:}

Evaluation de l'état foetal paranalyse automatique du rythme cardiaque

2. La surface de ralentissement du rythme cardiaque foetal et le pH du sang de l'artère ombilicale

La surface de ralentissement du rythme cardiaque foetal (RCF) a été étudiée afin d'évaluer sa valeur pronostique de l'état du nouveau-né.

\section{Patients et methode:}

Pour un groupe de 107 patients nous avons comparé trois types de surface de ralentissement: Aire «totale» $\left(A_{t}\right)$, "Aire résiduelle» $\left(A_{r}\right)$ entre les contractions utérines, (CU) et "Aire simultançe» $\left(A_{s}\right)$ pendant les $C U$ (Fig. 1 ). Les signaux initiaux employés étaient l'électrocardiogramme foetal et la pression intra-utérine. Les deux signaux étaient transmis au petit ordinateur construit spécialement pour la mesure des surfaces de ralentissement du RCF. Les résultats étaient présentés sous deux formes: graphique et numérique. Le RCF était exprimé en périodes, donc en unités de temps. Les deux dimensions des surfaces de ralentissement étaient exprimées en secondes. L'unité de surface sera donc la «secondecarrée» $s^{2}$. La somme des surfaces pour l'ensemble du tracé de chaque patiente a été ramenée à une Heure. Les résultats seront donc exprimés en "secondes au carré par heure» $\left(\mathrm{s}^{2} / \mathrm{h}\right)$. Le $\mathrm{pH} d u$ sang de l'artère ombilicale était mesuré deux fois. C'est la moyenne des deux chiffres qui a été retenue.

\section{Resultats:}

1. Le Tab. I montre la moyenne de chacune des trois surfaces de ralentissements.

2. La moyenne de chaque surface était, d'une façon statistiquement significative, plus grande pour les groupes des nouveau-nés avec $\mathrm{pH}$ bas $(<7.20)$.

3. Les Figs. 3a, b et $\mathbf{c}$ montrent la relation entre surfaces et $\mathrm{pH}$.

4. Le Tab. II fait apparaitre que le cocfficient de correlation le plus haut a été obtenu avec la surface totale $A_{t}$. 
5. Les «seuils d'alarme» obtenus pour la prediction du score d'Apgar normal ou bas [5] ont été testés pour le pH du sang artériel ombilical (Fig. 4). Il existe une différence significative pour les deux groupes de patients séparés par chaque seuil. Les Figs. 5, 6 et 7 montrent la répartition du $\mathrm{pH}$ de l'artère ombilicale pour deux groupes de surface: au dessus et au dessous du seuil d'alarme.

\section{Commentaires:}

La mesure des surfaces de ralentissement du RCF décrite par SUREAU depuis 1968 [7, 8, 9, 10,11] a été envisagée quand à sa valeur pour prédire l'état biologique du nouveau-né.

1. Il existe une assez bonne correlation entre les surfaces de ralentissement du RCF et le pH du sang artériel ombilical. Une correlation semblable avait été obtenue par SHELLEY [4] pour la surface totale et par TOURNAIRE [10] pour des surfaces réparties de façon légèrement différente. Les coefficients de correlation entre les surfaces de ralentissement et le score d'Apgar sont à des niveaux voisins de ceux du $\mathrm{pH}$.

2. Si l'on envisage la chronologie de la surface de ralentissement par rapport à la contraction utérine, il est surprenant de constater que le meilleur coefficient de correlation été obtenu pour la surface totale, suivie par la surface résiduelle et enfin par la surface simultanée.
Les résultats concordent avec ceux de SHELLEY [4] qui suggeraient qu'en pratique, la simple mesure de la surface totale de ralentissement serait suffisante, sans tenir compte de la chronologie par rapport à la contraction utérine, pour évaluer les tracés de RCF.

3. Le petit ordinateur construit par la groupe de recherche BAUDELOCQUE peut être utilisé directement, donc en pratique courante, ce qui n'était pas le cas pour la méthode manuelle [4] ou la méthode utilisant un important ordinateur programmé [10].

4. La mesure des surfaces de ralentissement nous semble présenter plusieurs avantages:

1. Elle fournit une évaluatiōn objective.

2. l'unité emplvyée est indépendante d'éléments tels que la vitesse d'enregistrement ou l'échelle du RCF.

3. Les données sont réduites: quelques chiffres remplacent les longues descriptions des classifications usuelles.

Conclusion:

Dans un groupe de 107 patients comprenant une forte proportion de grossesses à haut risque, la mesure des surfaces de ralentissement donne une évaluation objective du RCF avec des résultats sous une forme «concentrée». Elle fournit un asseż bon facteur pronostic des états clinique et biologique du nouveaú-né.

Mots-clés: Etat du nouveau né, état foetal, pH du saug de l'artère umbilicale, rythme cardiaque foetale, surface de ralentissement du rythme cardiaque foetal.

Aknowledgement: This paper is a work of the BAUDELOCQUE research group (Prof. F. LEPAGE) with grants from: DGRST 71. 7. 3023 74. 7. 0037, INSERM 71. 1. 492. 5, INSERM 74. 28. 7. 15, Fondation de France and Fondation pour la Recherche medicale francaise.

\section{Bibliography}

[1] HON, E. H., E. J. QUILLIGAN: The classification of fetal heart rate. II. A revised working classification. Connecticut Med. 31 (1967) 779

[2] Lepage, F., C. Sureau, J. Chavinie, M. CANNON, R. LE HOUEZEC: The need for technical progress in the study of the fetal heart rate. In: Huntingford, P. J., R. W. Beard, F. E. Hytten, J. W. Scopes: Perinatal Medicine. Second European Congress of Perinatal Medicine, London 1970. Karger, Basel 1971

[3] MYERS, R. E., E. MUELLER-HEUBACH, K. ADAMSONS: Predictability of the state of fetal oxygenation from a quantitative analysis of the components of late deceleration. Am. J. Obstet. Gynec. 115 (1973) 1083

[4] ShELley, T., R. TIPTON: Dip area. A quantitative measure of fetal heart rate pattern J. Obstet. Gynaec. Brit. Cwlth. 78 (1971) 694

[5] STURBOIS, G., M. TOURNAIRE, A. RIPOCHE, R. LE Houezec, G. Breart, J. Chavinie, C. SUREAU: Evaluation of the fetal state by automatic analysis of the heart rate: I. Deceleration areas and Apgar score J. Perinat. Med. 1 (1973) 235
[6] Sureau, C., J. Chavinié, M. Cannon: Some technical aspects of fetal electrocardiography. In: JACOBSON, B.: Seventh International Congress Medical of Biological Engineering, Stockholm 1967. Royal Academy of Engineering Sciences, Stockholm 1967

[7] Sureau, C., J. Chavinie, B. Míchelon, J. P. FELdMAN, M. CANNON, R. LE HounzeC: Le problème du rythme cardiaque foetal. Gyn. Obstét. 69 (1970) 259

[8] Sureau, C., J. Chavinie, M. L. Meżióu, R. LE HOUEZEC: Le rythme cardiaque foetal. Essai d'appréciation quantitative au cours du travail. J. Gyn. Obstet. Biol. Repr. 1 (1972) 249

[9] SUREAU, C.: Technical and theoretical problems in fetal heart rate monitoring Int. J. Gyn. Obstet. 10 (1972) 215

[10] TOURNAIRE, M., G. Y. YEH, A. FORSYTHE, E. H. HON: A study of fetal heart rate deceleration areas. I. Preliminary exploration. J. Obstet. Gynec. 42 (1973) 711

Received January 2, 1975. Accepted July 10, 1975.

Dr. M. Tournaire

Chef de Clinique-Assistant Université René Descartes Paris V/France 